\title{
Evidence for widespread distribution of piscidin antimicrobial peptides in teleost fish
}

\author{
U. Silphaduang ${ }^{1,3}$, A. Colorni ${ }^{2}$, E. J. Noga ${ }^{1, *}$ \\ ${ }^{1}$ Department of Clinical Sciences, College of Veterinary Medicine, North Carolina State University, \\ 4700 Hillsborough Street, Raleigh, North Carolina 27606, USA \\ ${ }^{2}$ Israel Oceanographic and Limnological Research, Ltd., National Center for Mariculture, \\ PO Box 1212, Eilat 88112, Israel
}

${ }^{3}$ Present address: Department of Food Science, University of Guelph, Guelph, Ontario N1G 2W1, Canada

\begin{abstract}
Antimicrobial peptides (AMPs) are increasingly recognized as a critical component of the host's defense against infection. Several types of AMPs have been recently identified from mucosal tissues or immune cells of a number of teleosts. Among these are the piscidins, which are 22 residue, $\alpha$-helical AMPs that were originally isolated from mast cells of hybrid striped bass Morone saxatilis male $\times$ Morone chrysops female. Using an antibody specific for the conserved N-terminal amino acid sequence of piscidin 1, we used immunohistochemistry to probe skin, gill, and gastrointestinal tract of 39 teleosts representing 7 different orders. Nine fish species were piscidin-positive, with all of these species being in the Perciformes, the largest and most evolutionarily advanced order of teleosts. Piscidin-positive cells were identified in species belonging to the families Moronidae, Serranidae, Sciaenidae, Siganidae and Belontidae. Immunopositive cells were usually most consistent with mast cells, although in some species, the granule appearance and tinctorial properties diverged somewhat from those of a typical piscine mast cell. In addition, rodlet cells were piscidin-positive in one member of the family Cichlidae; to our knowledge, it is the first time that a host-associated chemical biomarker has been identified in rodlet cells. Our data suggest that piscidins are present in many evolutionarily advanced teleosts. Piscidin-immunoreactive cells were most common at sites of pathogen entry, including the skin, gill and gastrointestinal tract. These results strongly suggest that piscidins are a widespread and important component of many fishes' defense against disease.
\end{abstract}

KEY WORDS: Piscidins $\cdot$ Mast cells $\cdot$ Rodlet cells $\cdot$ Innate immunity $\cdot$ Pisces Resale or republication not permitted without written consent of the publisher

\section{INTRODUCTION}

Antimicrobial peptides (AMPs) are host defense effector molecules present in virtually all life forms (Zasloff 2002). Surfaces of fish such as the skin, gills and gastrointestinal tract comprise a large area of delicate epithelium, and are the major routes of entry of pathogenic microorganisms. Even though these surfaces are continually exposed to a wide range of potential pathogens, healthy fish are capable of effectively limiting infection. Accumulative evidence is showing that antimicrobial peptides and small proteins may play a major role in protecting fish from such infections
(Jia et al. 2000). Several types of AMPs have been isolated from fish (see Noga \& Silphaduang [2003] for a review). These AMPs are present in tissues exposed to microorganisms such as mucosal surfaces and skin (Cole et al. 1997) and immune cells such as mast cells (Silphaduang \& Noga 2001, Murray et al. 2003). One type of AMP expressed by fish mast cells is piscidin (GenBank Nos. Q8UUG0, AAL40409, P0C006), a family of at least 3, potent, 22-amino acid peptides having a highly conserved, histidine-rich, phenylalanine-rich $\mathrm{N}$-terminus and a more variable C-terminus (Silphaduang \& Noga 2001). We previously found that piscidinimmunoreactive mast cells were distributed in various 
tissues of hybrid striped bass; the parental stocks of hybrid striped bass (white bass Morone chrysops and striped bass $M$. saxatilis) are in the family Moronidae, and similar appearing cells were positive in members of the family Sciaenidae (spot Leistomus xanthurus and Atlantic croaker Micropogonias undulatus). This prompted us to hypothesize that piscidins are present in other teleosts. To answer this question, we immunochemically examined tissues from 7 different orders of teleosts. Presumptively healthy, subadult to adult, farm-raised fish, as well as wild-caught individuals, were examined in the present study.

\section{MATERIALS AND METHODS}

Peptide synthesis. Piscidin 1 (both the entire peptide and an 11-mer fragment) and Magainin 2 peptides were synthesized using Fmoc chemistry on a Rainin Symphony instrument that provides on-instrument cleavage of the peptide from the resin. After synthesis, peptides were purified via analytical reverse phase HPLC using a YMC C-18 column $(4 \times 50$ mm, $3 \mu \mathrm{m}$ particle size, $120 \AA$ pore size support) using an acetonitrile gradient that was eluted at $1 \mathrm{ml} \mathrm{min}^{-1}$ where Buffer A was $0.05 \%$ trifluoro-acetic acid (TFA) in water and Buffer B was $80 \%$ acetonitrile in $0.05 \%$ TFA in water. Peptides were detected by their absorbance at $210 \mathrm{~nm}$. Mass spectrometry of an aliquot of each purified peptide was carried out on a Micromass TofSpec SE mass spectrometer that was operated in positive ion mode and that was equipped with a nitrogen laser $(337 \mathrm{~nm})$, a reflectron, delayed extraction and a post acceleration detector. The purified peptides were lyophilized from $0.05 \%$ TFA/acetonitrile solution and stored desiccated under argon gas until reconstitution in solvent.

Production of anti-piscidin antibodies. Anti-piscidin antibody was produced by a commercial laboratory (Bethyl Laboratories) using the company's standard procedures. Briefly, $2 \mathrm{mg}$ of an 11-mer peptide constituting the conserved N-terminus of piscidin 1 (FFHHIFRGIVH) was conjugated to keyhole limpet hemocyanin (KLH) using maleimide chemistry, which linked the peptide to KLH via a cysteine added to the N-terminal phenylalanine. The conjugation via the terminal amino acid allows tertiary conformation of the peptide that may be expected to mimic that in the native peptide, thus eliciting anti-conformational antibodies important for recognizing the native peptide. Immunogen was mixed with Complete Freund's adjuvant (1:1) and KLH-conjugated peptide was injected into $2 \mathrm{New}$ Zealand white rabbits biweekly at 5 subcutaneous sites $(0.2 \mathrm{ml}$ per site) using the following immunization schedule $\left(100 \mu \mathrm{g}\right.$ injection $\left.^{-1}\right)$ : Days $0,14,28$ and 42 . Thirty $\mathrm{ml}$ of antiserum was collected from each rabbit on Days 35 and 45. The antiserum was pooled and was then affinity-purified using the piscidin fragment conjugated to cyanogen bromide-activated agarose as an immunosorbent (10.5 mg of piscidin fragment was reacted with $15 \mathrm{~g}$ of agarose); $120 \mathrm{ml}$ of antiserum (two $30 \mathrm{ml}$ bleeds from 2 rabbits) was loaded onto the column (Uniflow 4, Sterogene). After washing, the affinity-purified antibody was eluted and concentrated.

This method produces $>0.1 \mathrm{mg}$ of peptide-specific antibody $\mathrm{ml}^{-1}$ of antiserum, as determined by recovered affinity-purified antibody. Antibody was $>95 \%$ immunoglobulin G (IgG), as determined by immunoelectrophoresis using antibodies specific for rabbit IgG, IgM and serum proteins. The titer of the antibody was determined via ELISA, using the piscidin fragment as the antigen coated onto a microtiter plate. The 11-mer peptide $\left(10 \mu \mathrm{g} \mathrm{ml}^{-1}\right.$ in phosphate-buffered saline [PBS], pH 7.2 to 7.5) was coated onto a microtiter plate at room temperature for $1 \mathrm{~h}$. The plate was then washed and post-coated with $1 \%$ BSA in PBS for $30 \mathrm{~min}$. The plate was washed and then dilutions of antibody in $1 \%$ BSA/PBS/0.01\% Tween 20 were added, beginning at $1 \mu \mathrm{g}$ antibody $\mathrm{ml}^{-1}$. After incubation for $1 \mathrm{~h}$, the plate was washed, followed by addition of peroxidase-conjugated goat anti-rabbit IgG (h\&l) in $1 \%$ BSA/PBS/0.01\% Tween 20. After incubation for $1 \mathrm{~h}$, the plate was washed and peroxidase substrate was added, incubated for $15 \mathrm{~min}$, and then stopped with $1 \mathrm{~N} \mathrm{HCl}$ (1:1). The absorbance was then read at $450 \mathrm{~nm}$. The titer was read as the reciprocal of the antibody dilution (dilution of a $1 \mathrm{mg} \mathrm{ml}^{-1}$ solution) that produced a net optical density of 1.0, compared to a blank (non-coated well), which had an optical density (OD) $<0.1$. The titer of the antibody used in all assays was approximately 1:18 000 .

The peptide-specific antibody had less than $1 \%$ cross-reactivity by ELISA, where $1 \%$ cross-reactivity is 100 times more antibody than is required to produce the same optical density with either free $\mathrm{KLH}$, conjugated KLH, or free peptide that shares less than 3 amino acids in the sequence.

Tissue collection. We used 39 teleosts (38 species and 1 hybrid) from various habitats (see Table 1) in this study. All fish were adults and appeared clinically normal at the time of sampling. Fish were euthanized with either buffered tricaine overdose or cold shock. Tissue samples were collected from at least 3 individuals of each species. For small fish, the peritoneal cavity was cut open and then the entire fish was fixed in $10 \%$ neutral-buffered formalin (NBF). For large fish, organ and tissue samples were collected at necropsy and fixed separately.

Routine histology. Skin from scaled fish, as well as gills, were decalcified overnight in either $10 \%$ formic acid or $10 \%$ EDTA. After embedding in paraffin, 
blocks were serially sectioned at a thickness of $5 \mu \mathrm{m}$. All sections were stained with hematoxylin and eosin (H\&E). In one case, a clinically normal fish was found to have granulomatous lesions. In this case, the lesions were also stained with Ziehl-Nielsen.

Immunohistochemistry (IHC). Serial sections were deparaffinized in xylene and rehydrated. Slides were then blocked with goat serum for $20 \mathrm{~min}$, and incubated with either nonimmune serum or monospecific, affinity-purified polyclonal anti-piscidin antibody $\left(20 \mu \mathrm{g} \mathrm{ml} \mathrm{m}^{-1}\right)$ for $30 \mathrm{~min}$ at room temperature. After washing with PBS, slides were incubated with biotinylated goat anti-rabbit serum (Biogenex) for $20 \mathrm{~min}$, followed by streptavidin-conjugated horseradish peroxidase (Biogenex). Enzyme activity was detected with DAB (3, 3'-diaminobenzidine). Slides were counterstained with Meyer's hematoxylin and Alcian blue. Photographs were made with an Olympus Vanox microscope. Slides were evaluated blindly. Negative controls were produced by substituting anti-piscidin antibody with nonimmune rabbit serum.

Confirmation of specificity of anti-piscidin antibody probe. Selected piscidin-positive tissues were further confirmed as positive with a blocking experiment. We incubated $100 \mu \mathrm{l}$ of piscidin 1 (FFHHIFRGIVHVGKTIHRLVTG, GenBank Accession No. Q8UUG0) or the unrelated peptide Magainin $2\left(40 \mu \mathrm{g} \mathrm{ml}^{-1}\right)$ with antipiscidin antibody $\left(5.6 \mu \mathrm{g} \mathrm{ml}^{-1}\right)$ for $30 \mathrm{~min}$ at room temperature before adding the antibody to the section (Polak \& Van Noorden 1984). The absence of immunoreactivity in the piscidin 1-treated section and the presence of a piscidin-positive reaction in the Magainin 2-treated section were considered confirmatory that the reaction was specific for piscidin.

\section{RESULTS}

\section{Specificity of test and effect of tissue preservation on immunoreactivity}

Some tissues consistently stained nonspecifically in most fish (i.e. false-positives), including cartilage, muscle, serosa of the alimentary tract, and capsules of the spleen and liver. These tissues were stained homogeneously in both antibody-treated sections and in the negative control.

We used NBF to fix all tissues in this study. The length of fixation time ( $7 \mathrm{~d}$ to $1 \mathrm{yr}$ ) did not have any apparent effect on immunoreactivity. However, sections that were cut from paraffin blocks that had been stored for more than 6 mo prior to testing seemed to lose immunoreactivity, suggesting that the piscidin epitopes that are reacting with the anti-piscidin antibody may be altered in tissues that are kept for a long period of time in paraffin. In some tissues such as the gill and skin, decalcification methods were needed; when $10 \%$ formic acid or $10 \%$ EDTA was used to decalcify tissues, a positive signal was still observed.

\section{Taxonomic distribution of piscidin-positive cells}

Of the 38 species tested, 9 were immunopositive with the anti-piscidin antibody (Fig. 1); 9 positive species (together with hybrid striped bass) were in the order Perciformes: striped bass $M$. saxatilis, white bass $M$. chrysops, hybrid striped bass the $M$. saxatilis male $\times M$. chrysops female, European sea bass Dicentrarchus labrax (all in the Moronidae), snowy grouper Epinephelus niveatus (Serranidae), spot Leiostomus xanthurus, Atlantic croaker Micropogonias undulates (both in the Sciaenidae), rabbitfish Siganus rivulatus (Siganidae), pearl gourami Trichogaster leeri (Belontidae) and Nile tilapia Oreochromis niloticus (Cichlidae). All members tested of the families Cyprinidae, Salmonidae, Atherinidae, Poeciliidae, Centropomidae, Chandidae, Centrarchidae, Caranjidae, Lutjanidae, Sparidae, Nandidae, Pomacentridae, Pleuronectidae and Tetraodontidae were negative.

\section{Piscidin-positive cell types}

The most commonly identified piscidin-positive cells were mast cells (Table 1). Mast cells in fish are typically defined as cells within solid tissues that via H\&E display abundant, eosinophilic granules (Reite 1997). piscidin-positive granules were clearly evident in mast cells of striped bass, white bass, hybrid striped bass and European seabass (Fig. 2). While positive cells from other fish were also dispersed throughout solid tissues, the shape, size and abundance/presence of granules varied considerably. Spot and Atlantic croaker also had piscidin-positive cells that were strongly eosinophilic and were prominent in the skin, gill and gut; while distinct granules were not obvious in these cells, their appearance and tissue location was consistent with mast cells (Fig. 3). Many cells in snowy grouper gill were positive. While these cells were strongly eosinophilic, granules were not evident with H\&E. However, immunochemistry sections showed numerous very small granules in these cells. In addition, the eosinophilic cells in snowy grouper gill were not uniformly positive; cells that appeared morphologically indistinguishable via $H \& E$ could be either positive or negative (Fig. 3). The gastrointestinal tract of pearl gourami had immunopositive cells that varied considerably in immunoreactivity. Via H\&E, one cell population had large, distinct granules and had the 


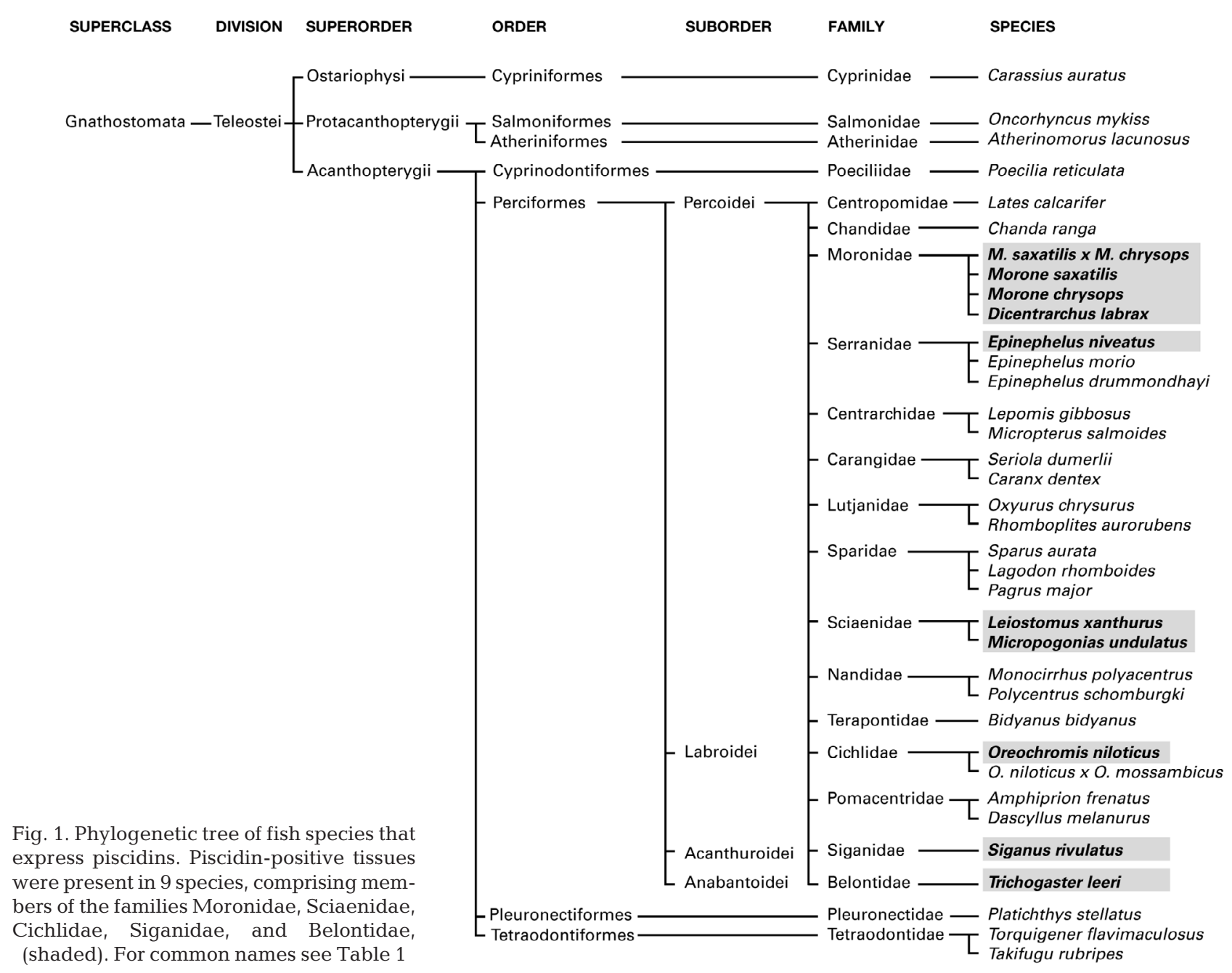

typical appearance of mast cells. However, these cells were not positive whereas another unidentified cell population with finely stippled cytoplasm was positive (Fig. 4).

Cells resembling mast cells were also piscidin-postive in rabbitfish (see 'Inflammatory lesions' below). One of 4 Nile tilapia Oreochromis niloticus (order Perciformes, suborder Labroidei, family Cichlidae), showed a positive signal in rodlet cells (Fig. 5). Only fish in the order Perciformes had piscidin-positive cells (Fig. 1).

\section{Tissue locations of piscidin-positive cells}

\section{Normal skin}

Skin of striped bass, white bass, hybrid striped bass, spot and Atlantic croaker possessed piscidin-positive cells. Intensely immunoreactive cells were observed in the epithelium and moderately strong cells were found in the connective tissue. Immunostaining of both mast cells and epithelial cells was observed in striped bass, white bass and hybrid striped bass.

\section{Normal gill}

Cells in the gill of striped bass, white bass, hybrid striped bass, spot, Atlantic croaker, snowy grouper, rabbitfish and pearl gourami were piscidin-positive. In some species, positive cells were within the connective tissue of the gill arch, as well as the primary and secondary lamellae. The most intense immunoreactivity was found in cells in the secondary lamellae and especially in the tip of the primary lamella, where there were many immunopositive cells. Cells in the connective tissue expressed a low or moderate signal intensity. All species with piscidin-positive cells on the lateral (lamellar) side of the gill also had piscidin-positive cells in the gill raker epithelium. 
Table 1. Cell and tissue distribution of piscidin-like peptides in fish. $\mathrm{C} / \mathrm{W}$ : cultured or wild; Tissues tested: $\mathrm{B}=\mathrm{brain}, \mathrm{G}=$ gill, $\mathrm{H}=$ heart, $\mathrm{I}=$ intestine, $\mathrm{K}=$ kidney, $\mathrm{L}=$ liver, $\mathrm{M}=$ mesentery, $\mathrm{P}=$ pancreas, $\mathrm{Sb}=$ swim bladder, $\mathrm{Sk}=\mathrm{skin}, \mathrm{Sp}=\mathrm{spleen}, \mathrm{St}=\mathrm{stomach}$; Blocking expt: fish for which at least 1 tissue section was further confirmed as positive by antibody blocking test (Y/N = blocking test/not done). For immunopositive cells, mast cells were defined as strongly eosinophilic or basophilic cells within solid tissues having abundant granules, and putative mast cells as cells within solid tissues in which granules were not as clearly evident; unknown cells could not be identified

\begin{tabular}{|c|c|c|c|c|c|c|c|}
\hline \multirow[t]{2}{*}{ Fish } & \multirow{2}{*}{$\begin{array}{l}\text { No. positive/ } \\
\text { no. examined }\end{array}$} & \multirow[t]{2}{*}{ Habitat } & \multirow[t]{2}{*}{$\mathrm{C} / \mathrm{W}$} & \multirow{2}{*}{ Tissues tested } & \multicolumn{2}{|c|}{ Immunopositive } & \multirow{2}{*}{$\begin{array}{c}\text { Blocking } \\
\text { expt }\end{array}$} \\
\hline & & & & & Tissues & Cells & \\
\hline $\begin{array}{l}\text { Striped bass } \\
\text { Morone saxatilis }\end{array}$ & $3 / 3$ & Brackish & $\mathrm{C}$ & $\begin{array}{l}\text { G, St, I, Sk, } \\
\text { SP, L }\end{array}$ & $\begin{array}{l}\text { G, St, I, Sk, } \\
\text { Sp, L }\end{array}$ & $\begin{array}{l}\text { Mast cells, } \\
\text { epithelial cells }\end{array}$ & $\mathrm{Y}$ \\
\hline $\begin{array}{l}\text { White bass } \\
\text { Morone chrysops }\end{array}$ & $3 / 3$ & Brackish & $\mathrm{C}$ & $\begin{array}{l}\text { G, St, I, Sk, } \\
\quad \text { SP, L }\end{array}$ & $\begin{array}{l}\text { G, St, I, Sk, } \\
\text { Sp }\end{array}$ & $\begin{array}{l}\text { Mast cells, } \\
\text { epithelial cells }\end{array}$ & $\mathrm{Y}$ \\
\hline $\begin{array}{l}\text { Hybrid striped bass } \\
\text { M. saxatilis } \times M \text {. chrysops }\end{array}$ & $10 / 10$ & Euryhaline & $\mathrm{C}$ & $\begin{array}{l}\text { G, St, I, Sk, Sp, } \\
\text { B, K, P, H, Sb, L }\end{array}$ & $\begin{array}{l}\mathrm{G}, \mathrm{St}, \mathrm{I}, \mathrm{Sk}_{1} \\
\mathrm{Sp}, \mathrm{K}\end{array}$ & $\begin{array}{l}\text { Mast cells, } \\
\text { epithelial cells }\end{array}$ & $\mathrm{Y}$ \\
\hline $\begin{array}{l}\text { European sea bass } \\
\text { Dicentrarchus labrax }\end{array}$ & $3 / 3$ & Marine & $\mathrm{W}$ & $\mathrm{G}, \mathrm{St}, \mathrm{I}$ & St, I & Mast cells & $\mathrm{Y}$ \\
\hline $\begin{array}{l}\text { Snowy grouper } \\
\text { Epinephelus niveatus }\end{array}$ & $1 / 1$ & Marine & $\mathrm{W}$ & $\mathrm{G}$ & $\mathrm{G}$ & Putative mast cells & $\mathrm{Y}$ \\
\hline $\begin{array}{l}\text { Spot } \\
\text { Leiostomus xanthurus }\end{array}$ & $4 / 4$ & Brackish & $\mathrm{W}$ & $\mathrm{G}, \mathrm{St}, \mathrm{I}, \mathrm{Sk}, \mathrm{Sp}$ & $\mathrm{G}, \mathrm{St}, \mathrm{I}, \mathrm{Sk}$ & Putative mast cells & $\mathrm{Y}$ \\
\hline $\begin{array}{l}\text { Atlantic croaker } \\
\text { Micropogonias undulatus }\end{array}$ & $3 / 3$ & Brackish & $\mathrm{W}$ & $\mathrm{G}, \mathrm{St}, \mathrm{I}, \mathrm{Sk}, \mathrm{Sp}$ & $\mathrm{G}, \mathrm{St}, \mathrm{I}, \mathrm{Sk}$ & Putative mast cells & $\mathrm{Y}$ \\
\hline $\begin{array}{l}\text { Nile tilapia } \\
\text { Oreochromis niloticus }\end{array}$ & $1 / 4$ & Freshwater & $\mathrm{C}$ & $\mathrm{G}, \mathrm{St}, \mathrm{I}, \mathrm{Sp}$ & $\mathrm{G}$ & Rodlet cells & $\mathrm{Y}$ \\
\hline $\begin{array}{l}\text { Rabbitfish } \\
\text { Siganus rivulatus }\end{array}$ & $1 / 7$ & Marine & $\mathrm{W}$ & G, St, I, P & $\mathrm{M}^{\mathrm{a}}$ & $\begin{array}{l}\text { Mast cells, } \\
\text { epithelioid cells }\end{array}$ & $\mathrm{Y}$ \\
\hline $\begin{array}{l}\text { Pearl gourami } \\
\text { Trichogaster leeri }\end{array}$ & $3 / 3$ & Freshwater & $\mathrm{C}$ & $\mathrm{G}, \mathrm{St}, \mathrm{I}, \mathrm{P}$ & $\mathrm{G}, \mathrm{St}, \mathrm{I}$ & Unknown cells & $\mathrm{N}$ \\
\hline
\end{tabular}

Rodlet cells in the gill of 1 of 4 Nile tilapia showed a very strong positive signal (Fig. 5). This positive signal was confirmed by the blocking experiment (Table 1). Only a small number of rodlet cells in the primary lamellae were positive. The single fish that was positive also had what appeared to be some type of arthropod ectoparasite (possibly an Argulus sp.) in the lamellae.

\section{Normal gastrointestinal tract}

Striped bass, white bass, hybrid striped bass, European sea bass, spot, Atlantic croaker and pearl gourami had piscidin-positive cells in the stomach and intestine (Figs. 2, $3 \& 4$ ). Cells in both areas of the stomach (corpus ventriculi and gastric ceca) were piscidin-positive. Positive cells resided within the lamina propria, gastric glands and columnar epithelium. Cells in the lamina propria showed weak to moderate signal, while cells in the gastric glands and between the columnar epithelial cells had the most intense immunoreactivity. Positive cells were also present in the submucosa and the columnar epithelium. The most intensely positive cells were also found between the columnar epithelial cells near the surface of the intestine. A piscidin-negative population of mast cells was usually observed in the submucosa of the alimentary tract.

\section{Other normal tissues}

The pancreas of striped bass and hybrid striped bass had piscidin-positive mast cells. Most of the cells with a strong signal were among the pyramidal acinar cells and around blood vessels that supplied the pancreas. In one striped bass, there were a number of positive mast cells surrounding a hepatic vein. We also observed immunoreactive cells in the spleen of hybrid striped bass and the renal tissue of striped bass. Positive mast cells with a strong signal were also found in the head kidney of striped bass.

\section{Inflammatory lesions}

Upon necropsy, a clinically normal, wild-caught rabbitfish presented with focal, chronic inflammatory lesions in the mesentery. The fish was diagnosed with presumptive Mycobacterium sp. infection based upon 

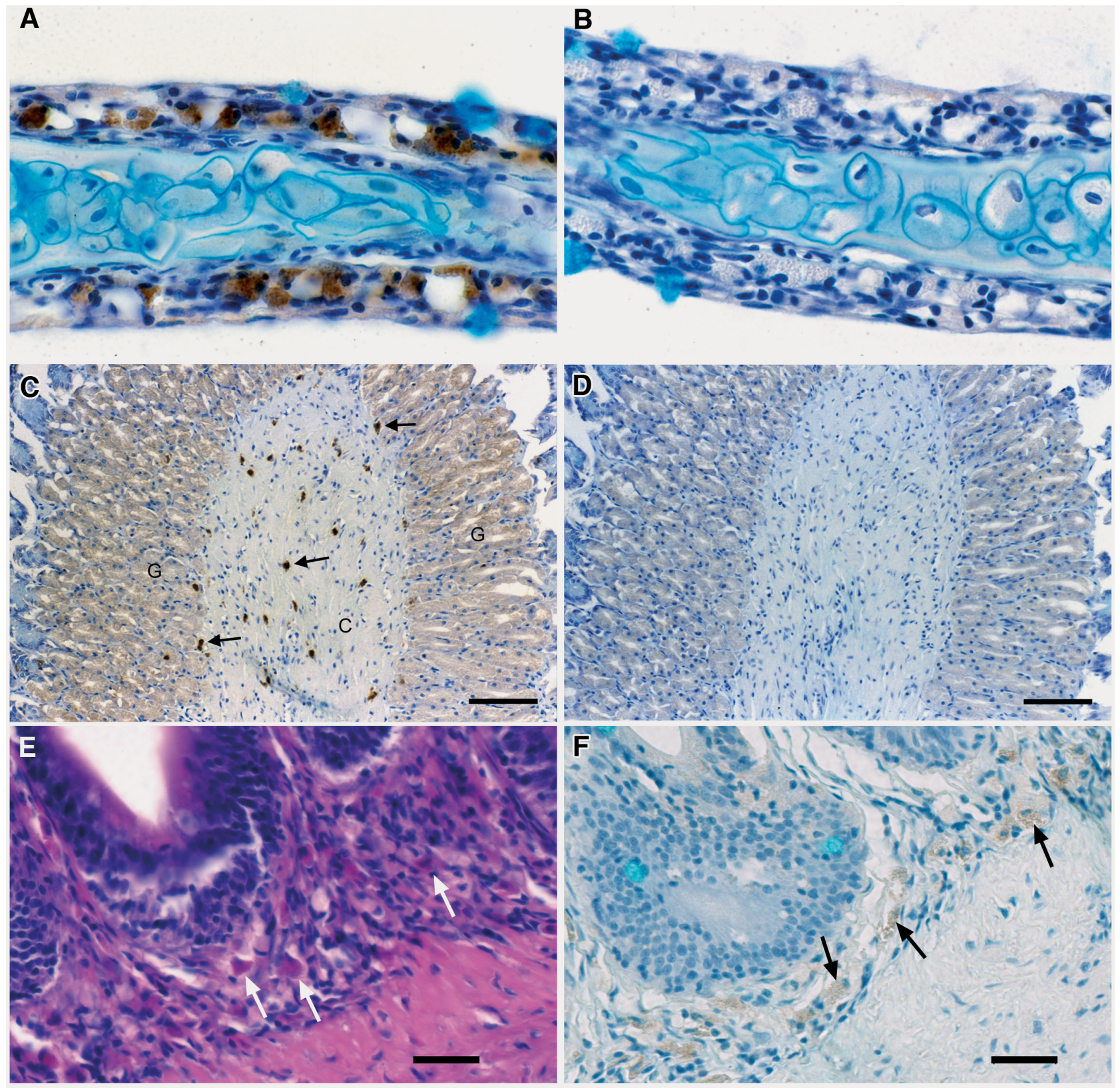

Fig. 2. Immunohistochemical localization of piscidin-positive mast cells in normal tissues of members of the family Moronidae (suborder Percoidei) treated with anti-piscidin antibody. $(\mathrm{A}, \mathrm{B})$ Hybrid striped bass Morone saxatilis $\times$ M. chrysops: (A) Immunopositive mast cells in primary gill lamella; (B) nonimmune serum control of serial section of (A). (C to F) European sea bass Dicentrarchus labrax: (C) Stomach with positive mast cells (arrows) in connective tissue (C) $(\mathrm{G}=$ cardiac gland cells); (D) nonimmune serum control of serial section of $(C)$; H\&E (E) of higher power magnification section of (C) showing mast cells in submucosa (arrows); (F) immunopositive mast cells (arrows) in serial section of (E). Scale bars $=20 \mu \mathrm{m}$

the presence of acid-fast bacteria in the granulomatous lesions. There were numerous immunopositive cells with abundant, fine, basophilic granules within these granulomata. Epitheloid cells in the granulomatous lesions also showed a weakly positive signal (Fig. 5). Subsequent examination of 6 additional rabbitfish (3 apparently normal and 3 having systemic granulomatous lesions) were all piscidin-negative.

\section{DISCUSSION}

\section{Piscidins detected by the IHC assay}

The anti-piscidin antibody that we used was a rabbit polyclonal antibody raised against the N-terminal 11 amino acid fragment of piscidin 1. This antibody also cross-reacts with piscidin 2 , since its N-terminus 

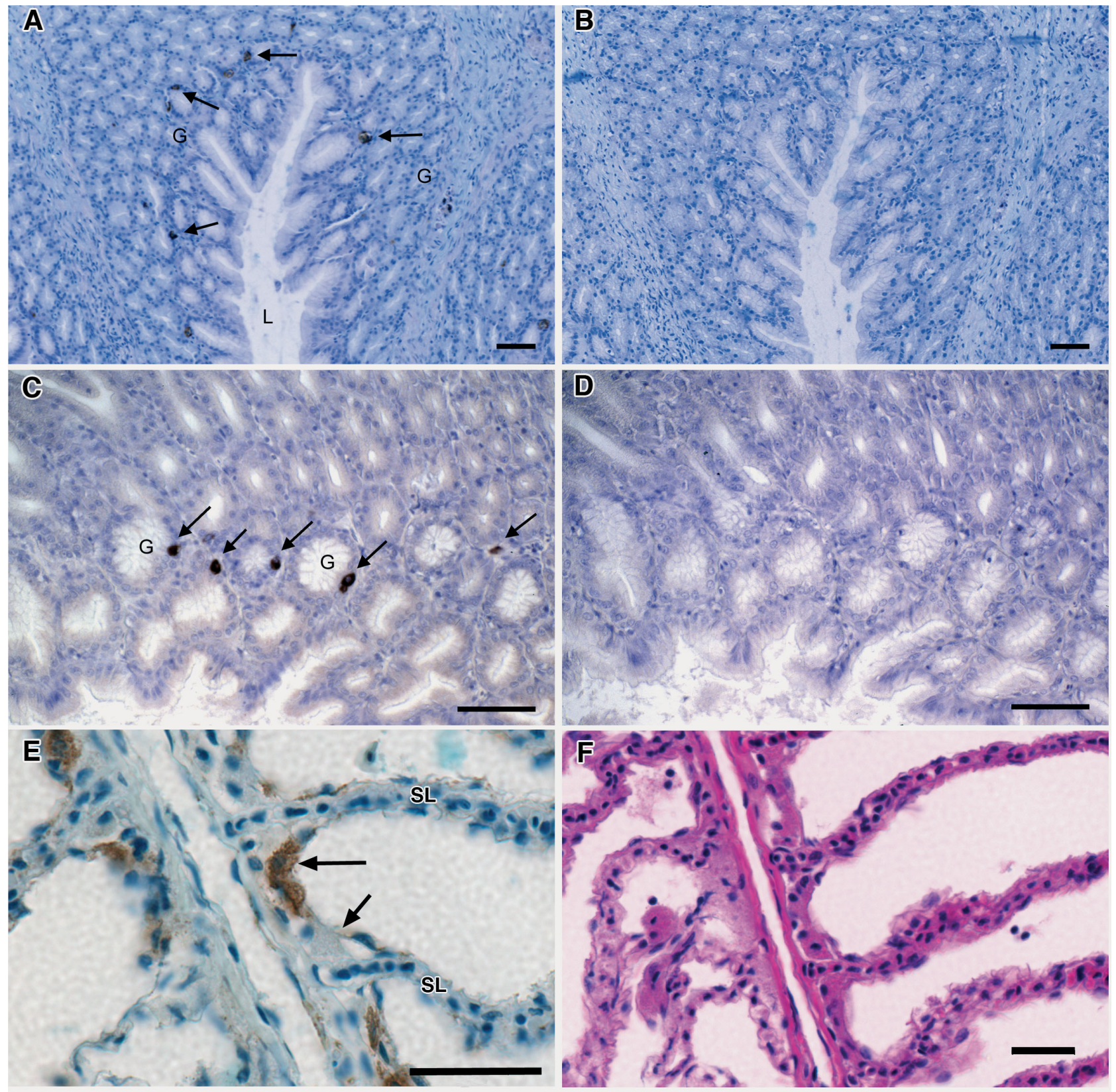

Fig. 3. Piscidin-positive cells in members of the suborder Percoidei treated with anti-piscidin antibody. (A,B) Spot Leiostomus xanthurus (family Sciaenidae); (A) stomach with positive cells (arrows) in the cardiac glandular area (G) (L: lumen); (B) nonimmune serum control of serial section of $(A)$. $(C, D)$ Croaker Micropogonias undulatus (family Sciaenidae): (C) stomach showing positive cells (arrows) in cardiac glands (G); (D) nonimmune serum control of serial section of (C). (E,F) Snowy grouper Epinephelus niveatus (family Serranidae): (E) immunopositive cells at base of the secondary lamella (SL) of the gill; note that these cells vary greatly in their immunopositive response, ranging from strongly positive (large arrow) to negative (small arrow); (F) H\&E of a serial section of $(E)$; note that eosinophilic cells at base of SL appear indistinguishable, even though they vary greatly in their immunoreactivity. Scale bars $=20 \mu \mathrm{m}$

is identical to that of piscidin 1 . It also probably cross-reacts strongly with piscidin 3 , since the $\mathrm{N}$-terminus of the latter only varies from that of piscidin 1 in having a relatively conservative substitution at Position 2 (Silphaduang \& Noga 2001). Thus, we could not determine if there was differen- tial expression of the various piscidins. The specificity of this antibody for piscidins was confirmed by our ability to specifically and totally neutralize the response by pre-incubating the antibody with piscidin 1. Incubating an unrelated antimicrobial peptide, Magainin 2, with the antibody showed no 

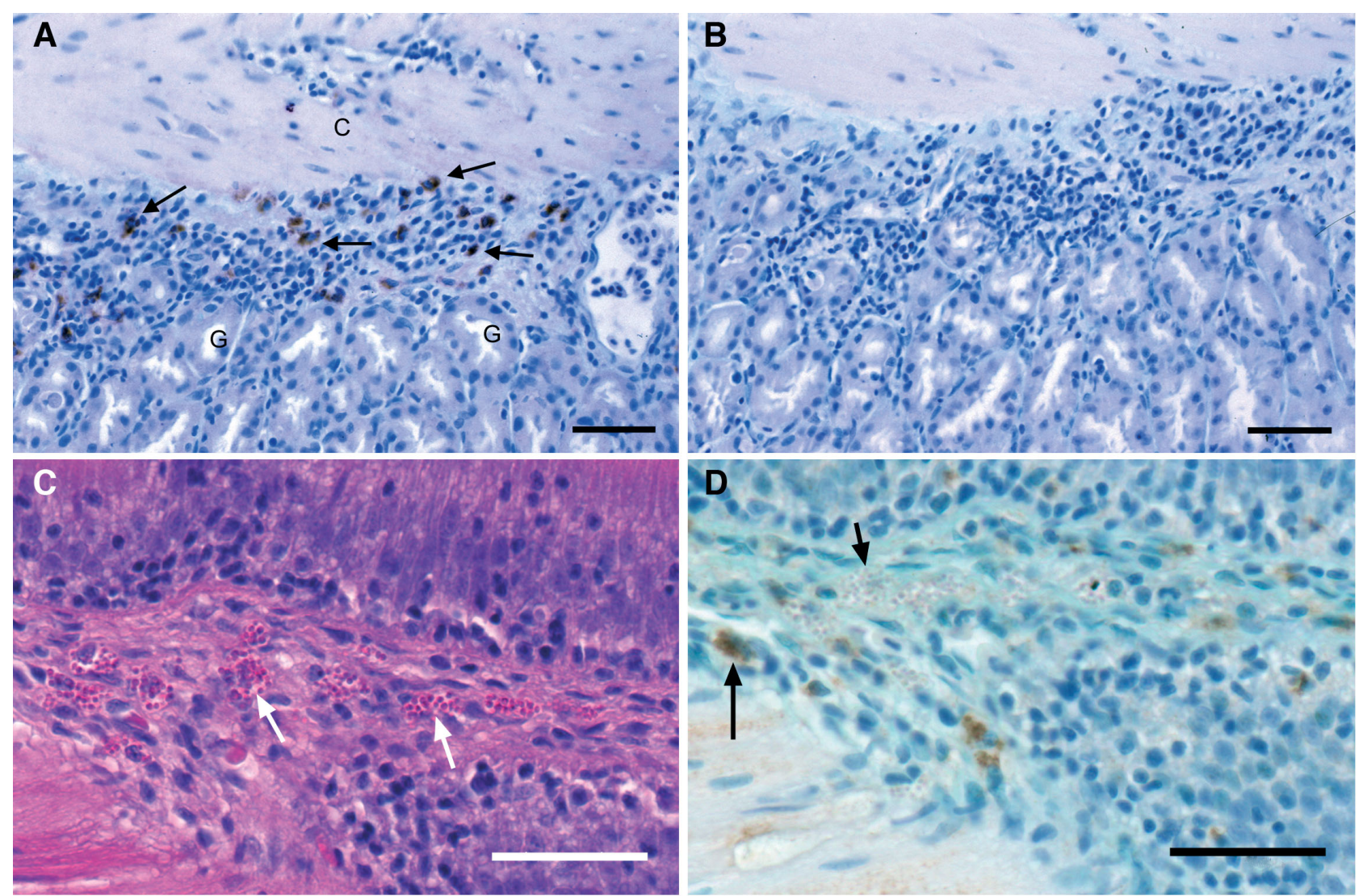

Fig. 4. Pearl gourami Trichogaster leeri. Piscidin-positive cells in a member of the suborder Anabantoidei (family Belontidae) treated with anti-piscidin antibody. (A) Immunopositive cells (arrows) in stomach $(\mathrm{G}=$ cardiac glands, $\mathrm{C}=$ connective tissue; note variability in staining intensity; (B) nonimmune serum control of serial section of (A); (C) H\&E of intestine, showing prominent mast cells with abundant, large granules in submucosa (arrows); (D) immunopositive cells in serial section of (C); note that the strongly immunopositive cells (large arrow) are not those with large granules (small arrow) in (C). Scale bars $=20 \mu \mathrm{m}$

effect on immunostaining on any of the tissues tested in the blocking experiment (Table 1).

The relatively short sequence that we used to create our anti-piscidin antibody makes it possible that some unrelated proteins might have cross-reacted with this peptide sequence. However, this 11-mer peptide fragment constitutes $50 \%$ of the entire piscidin sequence and 10 to 11 mer peptides are routinely used to generate antibody probes (W. Gordon, Bethyl Laboratories, pers. comm). In addition, the complete 22-mer piscidin 1 peptide totally abrogated the antibody signal while an unrelated alpha-helical AMP (Magainin) had no effect. Producing an antibody against the entire 22 amino acid piscidin 1 sequence (a linear peptide) would be very unlikely to eliminate any possible crossreactivity (as was indicated by our blocking experiment) and would have the disadvantage of selectively probing for peptides related to piscidin 1 at the expense of those more similar to piscidins 2 and 3 . While we cannot be certain, the N-terminus of the piscidins is the region that is most likely to be homologous among various fish species and thus using the entire piscidin 1 peptide might result in a less effective probe.

Also, the interpretation of IHC data must always be made within the context of the tissue being examined. We found that a single type of immune cell, the mast cell, was the predominant positive cell type. Other positive tissues that we identified are also known sites of AMP expression in other animals (e.g. other immunocytes, epithelia) and our probe did not react with tissues not known to be sites of AMP storage. Definitive proof of the presence of piscidins in these fish will require isolation of the peptide from each fish. Nonetheless, our data provides good evidence supporting the likely presence of piscidin-type peptides in these fish.

\section{Detection of piscidins in various fish species}

In order to investigate the host and tissue distribution of piscidins, we examined the tissues of 39 

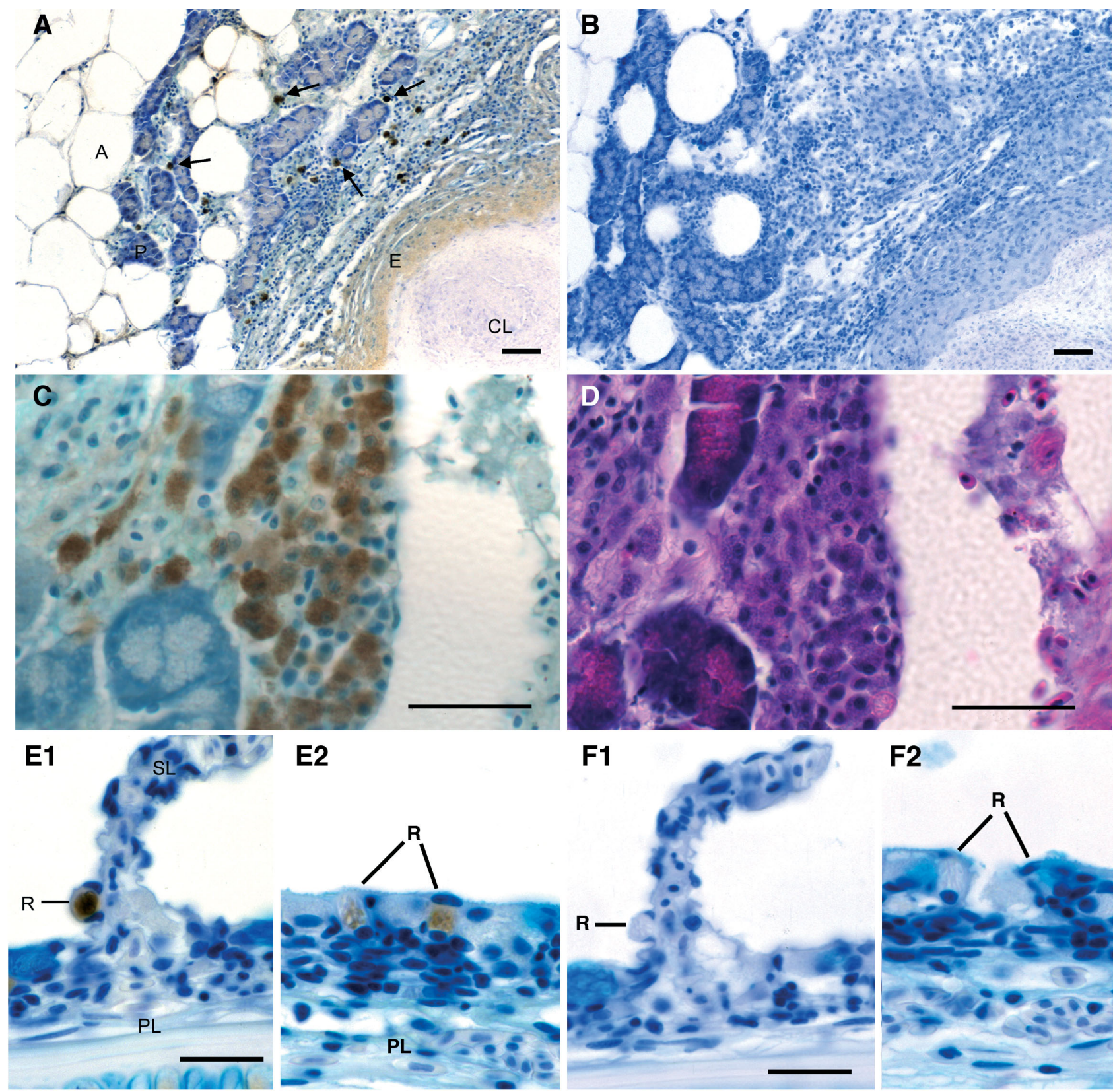

\section{E2}
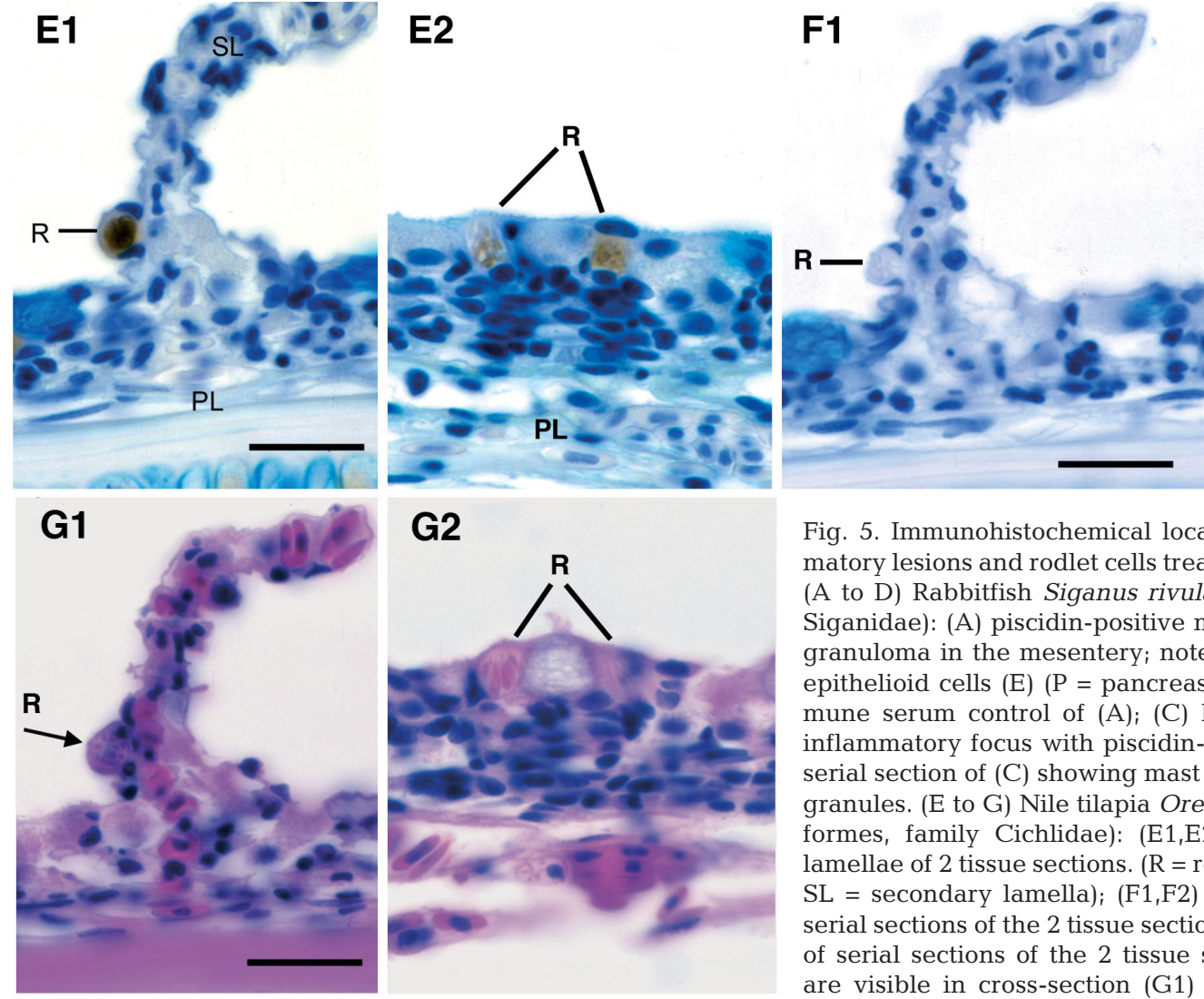

F2

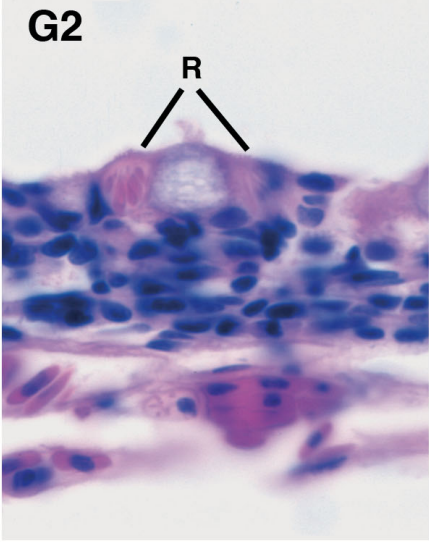

Fig. 5. Immunohistochemical localization of piscidins in inflammatory lesions and rodlet cells treated with anti-piscidin antibody. (A to D) Rabbitfish Siganus rivulatus (order Perciformes, family Siganidae): (A) piscidin-positive mast cells (arrows) infiltrating a granuloma in the mesentery; note also the less strongly positive epithelioid cells $(\mathrm{E})(\mathrm{P}=$ pancreas, $\mathrm{A}=$ adipose cells; $(\mathrm{B})$ nonimmune serum control of $(A) ;(C)$ higher power magnification of inflammatory focus with piscidin-positive mast cells; (D) H\&E of serial section of (C) showing mast cells with abundant, basophilic granules. (E to G) Nile tilapia Oreochromis niloticus (order Perciformes, family Cichlidae): (E1,E2) positive rodlet cells in gill lamellae of 2 tissue sections. $(\mathrm{R}=$ rodlet cell, $\mathrm{PL}=$ primary lamella, $\mathrm{SL}=$ secondary lamella); (F1,F2) nonimmune serum controls of serial sections of the 2 tissue sections in $(E) ;(G 1, G 2) H \& E$ staining of serial sections of the 2 tissue sections in $(E)$; rodlet granules are visible in cross-section (G1) and longitudinal section (G2). Scale bars $=20 \mu \mathrm{m}$ 
teleosts (38 species and 1 hybrid) from 7 different orders. We found immunopositive fish only in the order Perciformes (striped bass, white bass, hybrid striped bass, European sea bass, snowy grouper, spot, Atlantic croaker, rabbitfish, pearl gourami and Nile tilapia). These results suggest that piscidins are evolutionarily widespread within the order Perciformes, which is the largest living vertebrate order. It is also important to realize that a negative result in our test does not rule out the possibility that a species might possess a piscidin-like peptide, since the antibody probe might not cross-react with all peptides related to piscidin, or the fish might not have been expressing the peptide at the time of our sampling. For example, only 1 of 7 rabbitfish were piscidin-positive.

Some other types of polypeptide antibiotics have also been found in a wide range of fish. Various proteins and peptides that are closely related to nuclear core histones have been isolated from a taxonomically wide range of fish, including salmonids, ictalurids, silurids and moronids (Park et al. 1998, Robinette et al. 1998, Noga et al. 2002, Birkemo et al. 2003). Using genomic screening, a gene family encoding pleurocidin, an AMP in the skin mucus secretions of winter flounder Pleuronectes americanus, was also identified in other flatfish, including yellowtail flounder Limanda ferruginea, Atlantic halibut Hippoglossus hippoglossus, American plaice Hippoglossoides platessoides and witch flounder Glyptocephalus cynoglossus, all of which are in the order Pleuronectiformes. A number of sequences from these fish were used to synthesize pleurocidin analogues, some of which had potent activity against a number of bacterial pathogens (Douglas et al. 2001, Patrzykat et al. 2003). However, Douglas et al. (2001) were unable to detect the gene in fish outside this order, including haddock Melanogrammus aeglefinus, pollock Pollachius virens (both in the order Gadiformes) and smelt Osmerus mordax (order Salmoniformes).

An alternative to our proteomic approach to searching for evidence of piscidin-like peptides is to use nucleotide probes to attempt to amplify homologous coding sequences via PCR or in situ hybridization. Douglas et al. (2001) and Patrzykat et al. (2003) used this approach to identify homologous sequences of pleurocidin in various fish. However, genomic approaches such as in situ hybridization using oligonucleotide probes to locate related peptides have significant limitations since even if the amino acid sequences are highly similar, different species of fish may use different codons for the same amino acid, making it difficult to design probes that will recognize similar proteins.

\section{Tissue and cellular locations of piscidins}

The most common piscidin-positive cell type that we identified was the mast cell. Mast cells (also known in fish as eosinophilic granular cells) are tissue granulocytes. Although teleost mast cells are abundant around blood vessels and host-environment interfaces such as the skin, gills and alimentary tract, their function in defense is not clearly defined. Teleost mast cells store a number of mediators, such as phospholipids, alkaline phosphatase, aryl sulphatase B, 5-nucleotidase, acid phosphatase, peroxidase and lysozyme, which participate in bacterial inactivation and degradation (Ezeasor \& Stoke 1980, Powell et al. 1992, Sire \& Vernier 1995, Sveinbjørnsson et al. 1996, Lin et al. 1998). The presence of piscidins in mast cells of diverse fish species suggests that they perform some type of critical defensive function. There is some evidence that teleost mast cells can be phagocytic. Bodammer (1986) described engulfment of bacteria and formation of a phagosome in striped bass. Mast cells in the intestinal lamina propria of rainbow trout have phagocytic activity and can internalize latex beads into the cytoplasm (Sire \& Vernier 1995). Thus, if not released from mast cells via degranulation, piscidins might kill pathogens that are phagocytosed.

Recently, other AMPs have been discovered in mast cells. Chrysophsins, AMPs isolated from red sea bream Chrysophrys major reside in gill mast cells (Iijima et al. 2003). Pleurocidin is both synthesized and stored in gill mast cells of winter flounder (Murray et al. 2003). Both human and murine mast cells express AMPs called cathelicidins (caths). Mast cells that are co-cultured with bacteria reduce bacterial growth and they lose this capacity when they lack caths. This suggests that caths in mammalian mast cells provide a potent mechanism that enables mast cells to participate in defense against infection (Di Nardo et al. 2003).

The immunopositive cells in Morone spp., European seabass and rabbitfish were morphologically consistent with those of piscine mast cells. While cells in some other fish were also suggestive of mast cell origin (e.g. positive cells in snowy grouper, spot and croaker), their appearance was not completely typical of mast cells, especially in terms of granule morphology. Positive cells in other fish (e.g. pearl gourami) were even less typical of classical mast cells. Further morphological and functional studies are needed to confirm the identity of these various cells.

The most intense immunoreactivity that we observed was in cells in the secondary lamellae and the tip of the primary lamellae. Positive cells in connective tissue in the gill arch expressed low or moderate intensity signal. In the alimentary tract, the piscidin-positive cells showed a characteristic pattern in all positive fish. 
Cells in the lamina propria, stratum granulosum and stratum compactum of the intestine always showed less positive signal than those in the gastric glands of the stomach or between columnar epithelial cells of the stomach or intestine. These results might indicate that cells in the connective tissue of the alimentary tract start to synthesize piscidins as they begin to migrate to the luminal surface. A similar process may occur in the gills. If only the piscidin prepropeptide is present in connective tissue cells of the alimentary tract or gill, it may not be as immunoreactive with an antibody to the mature peptide. In contrast, cells near and at the surface of the gill and alimentary tract, which have a high risk of contacting pathogens, would be armed with the active form of piscidins that are well recognized by the antibody. An alternative explanation is that cells in the lamina propria/connective tissue of the gill may contain a greater proportion of piscidin 3, which is less hemolytic than piscidins 1 or 2 (Silphaduang \& Noga, 2001). Cells at the surface might contain a greater proportion of piscidins 1 and 2, which also might be more reactive with our anti-piscidin antibody.

An important observation is that some mast cells not only varied in intensity of immunoreactivity, but were also immunonegative. Mammalian mast cells are a heterogeneous group comprised of populations that differ in histochemical, biochemical, and functional characteristics (Welle 1997, Gurish \& Boyce 2002). Whether fish mast cells are also a heterogeneous population is unknown.

A piscidin-positive reaction was also seen in gill rodlet cells of a single Nile tilapia. The rodlet cell was originally described as a unicellular parasite (Thélohan 1892). However, there is some evidence that it might have a defense function. Local recruitment of rodlet cells has been associated with infections (viruses and especially parasites), toxins, neoplasia and general tissue damage (Reite 1997, 2005, Manera \& Dezfuli 2004, Reite \& Evensen 2006). Leino (1996) found that the presence of actively secreting rodlet cells in the renal tubular epithelium of bluegill Lepomis macrochirus infected with a myxozoan parasite appeared to be associated with the disappearance of the parasite infection. Interestingly, we observed a single metazoan ectoparasite (possibly an Argulus sp.) in the gill of this positive fish and no parasites in the negative Nile tilapia. Because of the very limited data, we are not certain whether the expression of piscidins in rodlet cells of this tilapia might be induced. However, to our knowledge, this is the first time that a specific protein linked directly to the host has been identified in rodlet cells, providing additional evidence that these cells are of host origin.

The epithelioid cells in a single fish having presumptive Mycobacterium sp. induced granulomata were also positive for piscidin. As with the rodlet cell observation, the limited sampling precludes any far-reaching conclusions, but other AMPs have been known to be upregulated with chronic infections (Lehmann et al. 2002, Butmarc et al. 2004). In regards to infected fish that were negative, antimicrobial polypeptides can vary significantly within individuals within a species (even healthy appearing individuals), as we have shown for HLP-1 and callinectin (Noga et al. 1994, Robinette et al. 2001), and others have shown for other AMP. Also, we do not know what regulates the expression of piscidin in all these different fish species and some piscidin-like peptides might be not be constitutive but only expressed after a certain stimulus.

There was also some evidence that other cell types, including epidermal epithelium, were also piscidinpositive. While we cannot entirely rule out the possibility that some tissues might be false-positive, other AMPs can be expressed in a number of different cell types, including the epithelium (Zasloff 2002).

In summary, our evidence that mast cells, rodlet cells and other cell types of teleosts from a wide taxonomic range of species express piscidins and the abundance of these cells in various tissues at high risk of infection suggest that piscidins play a significant role in the nonspecific immune defense of many teleosts.

Acknowledgements. We thank M. Mattmuller for excellent assistance with immunochemistry, W. L. Gordon for assistance with antibody production, J. Crawford (Yale University) for assistance with peptide synthesis, and R. J. Goldstein (R. J. Goldstein and associates), S. Wada (Nippon Veterinary and Animal Science University), T. Wenzel and L. Brothers (Carolina Fisheries) for providing fish. This work was supported by Research Grant No. US-3030-98 from BARD, the United States-Israel Binational Agricultural Research and Development Fund, Grant No. NA46RG0087 from the National Sea Grant College Program, National Oceanic and Atmospheric Administration, to the North Carolina Sea Grant College Program, and Grant No. 02-AM-01 from the North Carolina Fishery Research Grant Program.

\section{LITERATURE CITED}

Birkemo GA, Luders T, Andersen A, Nes IF, Nissen-Meyer J (2003) Hipposin, a histone-derived antimicrobial peptide in Atlantic halibut (Hippoglossus hippoglossus L.). Biochim Biophys Acta 1646:207-215

Bodammer JE (1986) Ultrastructural observations on peritoneal exudate cells from the striped bass. Vet Immunol Immunopathol 12:127-140

Butmarc J, Yufit T, Carson P, Falanga V (2004) Human $\beta$ defensin-2 expression is increased in chronic wounds. Wound Repair Regen 12:439-443

Cole AM, Weis P, Diamond G (1997) Isolation and characterization of pleurocidin, an antimicrobial peptide in the skin secretions of winter flounder. J Biol Chem 272: 12008-12013

Di Nardo A, Vitiello A, Gallo RL (2003) Cutting edge: Mast cell antimicrobial activity is mediated by expression of 
cathelicidin antimicrobial peptide. $\mathrm{J}$ Immunol 170: 2274-2278

Douglas SE, Gallant JW, Gong Z, Hew C (2001) Cloning and developmental expression of a family of pleurocidin like antimicrobial peptides from winter flounder, Pleuronectes americanus (Walbaum). Dev Comp Immunol 25: 137-147

Ezeasor DN, Stoke WM (1980) A cytochemical, light and electron microscopic study of the eosinophilic granule cells in the gut of the rainbow trout, Salmo gairdneri Richardson. J Fish Biol 17:619-634

Gurish MF, Boyce JA (2002) Mast cell growth, differentiation, and death. Clin Rev Allergy Immunol 22:107-118

Iijima N, Tanimoto N, Emoto $\mathrm{Y}$, Morita $\mathrm{Y}$, Uematsu $\mathrm{K}$ Murakami T, Nakai T (2003) Purification and characterization of three isoforms of chrysophsin, a novel antimicrobial peptide in the gills of the red sea bream, Chrysophrys major. Eur J Biochem 270:675-686

Jia X, Patrzykat A, Devlin RH, Ackerman PA, Iwama GK, Hancock RE (2000) Antimicrobial peptides protect coho salmon from Vibrio anguillarum infections. Appl Environ Microbiol 66:1928-1932

Lehmann J, Retz M, Harder J, Krams M and 8 others (2002) Expression of human $\beta$-defensins 1 and 2 in kidneys with chronic bacterial infection. BMC Infect Dis 2:20 (also available at: www.biomedcentral.com/1471-2334/2/20)

Leino RL (1996) Reaction of rodlet cells to a myxosporean infection in kidney of the bluegill, Lepomis macrochirus. Can J Zool 74:217-225

Lin SH, Davidson GA, Secombes CJ, Ellis AE (1998) A morphological study of cells isolated from the perfused gill of dab and Atlantic salmon. J Fish Biol 53:560-568

Manera M, Dezfuli BS (2004) Rodlet cells in teleosts: a new insight into their nature and function. J Fish Biol 65: 597-619

Murray HM, Gallant JW, Douglas SE (2003) Cellular localization of pleurocidin gene expression and synthesis in winter flounder gill using immunohistochemistry and in situ hybridization. Cell Tissue Res 312:197-202

Noga EJ, Silphaduang U (2003) piscidins: a novel family of peptide antibiotics from fish. Drug News Perspect 16: $87-92$

Noga EJ, Engel DP, Arroll TW, McKenna S, Davidian M (1994) Low serum antibacterial activity coincides with increased prevalence of shell disease in blue crabs, Callinectes sapidus. Dis Aquat Org 19:121-128

Noga EJ, Fan Z, Silphaduang U (2002) Host site of activity and cytological effects of histone like proteins on the parasitic dinoflagellate Amyloodinium ocellatum. Dis Aquat Org 52:207-215

Editorial responsibility: Donald Evans, Athens, Georgia, USA
Park IY, Park CB, Kim MS, Kim SC (1998) Parasin I, an antimicrobial peptide derived from histone H2A in the catfish, Parasilurus arosus. FEBS Lett 437:258-262

Patrzykat A, Gallant JW, Seo JK, Pytyck J, Douglas SE (2003). Novel antimicrobial peptides derived from flatfish genes. Antimicrob Agents Chemother 47:2464-2470

Polak JM, Van Noorden S (1984) Introduction to immunocytochemistry, 2nd edn. Springer-Verlag, New York

Powell MD, Briand HA, Wright GM, Burka JF (1992) Ultrastructural localisation of acid phosphatase in intestinal eosinophilic granule cells (EGC) of rainbow trout (Oncorhynchus mykiss) following degranulation with capsaicin. Histol Histopathol 7:301-305

Reite OB (1997) Mast cells/eosinophilic granule cells of salmonids: staining properties and responses to noxious agents. Fish Shellfish Immunol 7:567-584

Reite OB (2005) The rodlet cells of teleostean fish: their potential role in host defence in relation to the role of mast cells/eosinophilic granule cells. Fish Shellfish Immunol 19: 253-267

Reite OB, Evensen Ø (2006) Inflammatory cells of teleostean fish: a review focusing on mast cells/eosinophilic granule cells and rodlet cells. Fish Shellfish Immunol 20:192-208

Robinette DW, Noga EJ (2001) Histone-like protein (HLP): a novel method for measuring stress in fish. Dis Aquat Org 44:97-107

Robinette D, Wada S, Arroll T, Levy MG, Miller WL, Noga EJ (1998) Antimicrobial activity in the skin of the channel catfish Ictalurus punctatus: characterization of broad-spectrum histone-like antimicrobial proteins. Cell Mol Life Sci $54: 467-475$

Silphaduang U, Noga EJ (2001) Peptide antibiotics in mast cells of fish. Nature 414:268-269

Sire MF, Vernier JM (1995) Partial characterization of eosinophilic granule cells (EGCs) and identification of mast cells of the intestinal lamina propria in rainbow trout (Oncorhynchus mykiss). Biochemical and cytochemical study. Biol Cell 85:35-41

Sveinbjørnsson B, Olsen R, Paulsen S (1996) Immunocytochemical localization of lysozyme in intestinal eosinophilic granule cells (EGCs) of Atlantic salmon, Salmo salar L. J Fish Dis 19:349-355

Thélohan P (1892) Sur les sporozoares indeterminés parasites des poissons. J Anat Physiol Paris 28:163-171

Welle M (1997) Development, significance, and heterogeneity of mast cells with particular regard to the mast cell-specific proteases chymase and tryptase. J Leukoc Biol 61: 233-245

Zasloff M (2002) Antimicrobial peptides of multicellular organisms. Nature 415:389-395

Submitted: August 30, 2005; Accepted: June 26, 2006

Proofs received from author(s): October 23, 2006 